\title{
An energetic approach to the study of life-history traits of two modular colonial benthic invertebrates
}

\author{
Rafel Coma ${ }^{1, *}$, Marta Ribes $^{1}$, Josep-Maria Gili $^{1}$, Mikel Zabala ${ }^{2}$ \\ 'Institut de Ciències del Mar (CSIC), Passeig Joan de Borbó s/n, E-08039 Barcelona, Spain \\ ${ }^{2}$ Departament d'Ecologia, Universitat de Barcelona, Avda. Diagonal 645, E-08028 Barcelona, Spain
}

\begin{abstract}
In order to study contrasted ecological strategies and life-history traits of modular colonial organisms, the energy budgets of 2 common Mediterranean cnidarians, the hydroid Campanularia everta and the gorgonian Paramuricea clavata, were compared. C. everta is a small hydroid that forms stoloniferous colonies on ephemeral substrata. Adapted to an epibiotic life strategy, it produces small colonies with $6 \%$ of weight as structural material. Growth is very fast and much energy is allocated throughout the year to growth and it develops stolons which enable it to spread readily on the algal substratum. A colony may live for 2 to $6 \mathrm{wk}$. Maintaining high growth rates requires rapid metabolism supported by daily ingestion rates of more than $19 \%$ of body weight and commensurately high respiratory and excretory rates $(8.5 \%$ of body weight daily). Sexual reproduction in this gonochoric species is precocious and concentrated in autumn, when a daily effort equivalent to $4-10 \%$ of somatic biomass is expended on reproduction. The flow of energy through $C$. everta amounts to some $1915 \mathrm{cal} \mathrm{g} \mathrm{C}^{-1} \mathrm{~d}^{-1}$, with a mean turnover time of $12 \mathrm{~d}$. P. clavata forms large colonies with polyps 100 times larger than those of the hydroid. The skeleton consists of spicules and an organic skeletal axis which amount to 54 and $35 \%$, respectively, of the colonies' total biomass. Growth is slower than in C. everta, equivalent to $0.15 \%$ of tissue weight daily, with a turnover rate of $9 \mathrm{yr}$. The main energetic component $(72 \%)$ is basal metabolism. From March to June, daily investment in reproduction is equivalent to $0.4-0.7 \%$ of

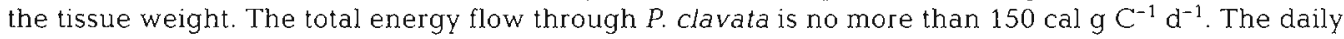
energy demand is $1.43 \%$ of tissue weight or $3 \%$ of total dry weight. Although they exhibit quite different ecological strategies, which appear to be regulated mainly by trophic and substratum constraints, the 2 species have certain life-history traits in common. In annual budgetary terms, reproductive effort is similar in both species, substratum constraints notwithstanding, and concentrated in a period of the year favourable to the survival of offspring. The results suggest that, at least in seasonal seas like the Mediterranean, an energetic approach can provide an important contribution to the understanding of life-history traits of modular colonial organisms.
\end{abstract}

KEY WORDS: Energy budget - Life history - Resource allocation - Reproductive effort - Somatic investment - Gorgonian - Hydroid - Mediterranean

\section{INTRODUCTION}

Certain ecological theories developed for aclonal organisms may not be directly applicable to clonal organisms (e.g. Jackson et al. 1985). Life-history theory has been used to predict patterns of somatic and reproductive investments under varying regimes of environmental conditions and mortality (reviewed in Stearns 1977, 1992), but always from the standpoint of aclonal

•E-mail: coma@ism.csic.es organisms. Sebens (1979) and Hughes \& Cancino (1985) carried out a specific analysis of the repercussions of cloning on life histories and adapted the predictive framework to the domain of clonal organisms. In the words of Hughes \& Cancino (1985), ' '...It is evident that the clonal soma, resulting from unitary replication, is characterized by great morphological flexibility, by a potential to accumulate large biomass, and often by a potential to grow rapidly. As elaborated upon below, these characteristics tend to be polarized toward (1) rapid proliferation and efficient dispersal of 
units in clones opportunistically exploiting temporally or spatially variable patches of resources or (2) larger aggregations of biomass in sedentary species competitively acquiring space on relatively persistent substrata'. However, theoretical efforts to study clonal organisms have not been matched by sufficient experimental evidence (Hughes \& Jackson 1985, Jackson 1985, Hughes 1989).

Fisher's (1958) life-history theory attempted to explain the budgeting of matter and energy among reproduction, growth and maintenance in terms of natural selection. Later developments in life-history theory focused on the adaptive basis of demographic traits, such as spawning size, parity, and precocity in sexual maturity, in age-classified populations, under the premise that these traits should maximize expected lifetime reproductive output (Caswell 1989). There have been a number of models predicting interactions among age-specific sets of life-history traits (Caswell 1982, 1989). These models are difficult to apply to clonal animals because it is problematical to measure the fecundity and growth of an individual that can survive as morphologically disconnected pieces (Jackson et al. 1985). Furthermore, these models cannot account for the selective value of investments in maintenance and growth, which can be extremely important in clonal organisms.

In the Mediterranean, as in other temperate seas, the seasonal variation of important environmental factors such as temperature, food availability and photoperiod (Zabala \& Ballesteros 1989) can cause shifts in resource allocation of benthic modular organisms. The energetics approach can examine how matter and energy are invested in reproduction, growth and maintenance throughout the year. Consequently, energetics can provide a complementary approach to the understanding of life history of modular colonial organisms, where demographic models are insensitive to the timing of activity patterns such as reproductive and growth events

The energetics of cnidaria were reviewed by Sebens (1987) However, most contributions have been incomplete and have been biassed towards a clear preference for such aspects as growth, feeding, and reproductive cycles. The quantification of the components of the energy budget should be as thorough as possible, carried out separately for the different age classes, and performed over an entire annual cycle. The object of this paper is to compare, based on their resource allocation strategies, the ecological tactics and life histories of 2 modular colonial organisms that both dwell in the same community and are taxonomically related (same phylum), but whose clones are at opposite ends of the spectrum in terms of colony size, organization, and longevity, i.e. the small stoloniferous hydroid Campanularia everta (Clarke, 1876) and the large upright gorgonian Paramuricea clavata (Risso, 1826).

\section{MATERIAL AND METHODS}

Some of the data used in this work have been published in previous, more specific work on the feeding, reproduction and growth of both species. These sources are cited, as appropriate, in respective sections of the 'Materials and methods'. The different sources of variation considered for each of these 3 components of the energy budget are shown in Table 1.

Daily energy intake. Stomach contents were estimated by examining 3 sources of variation in Para-

Table 1 Campanularia everta and Paramuricea clavata. Sources of variation examined for feeding, reproduction and growth of these 2 species and studies in which these variations were examined. Intra-colonial refers to position within the colony; digestion refers to time required for prey digestion and longevity refers to life-span of gonangia

\begin{tabular}{|c|c|c|c|c|c|c|}
\hline & & \multicolumn{4}{|c|}{ Source of variation } & \multirow{2}{*}{ Reference } \\
\hline & & Season & Diel & Intra-colonial & Digestion & \\
\hline \multirow[t]{3}{*}{ Feeding } & C. everta & $x$ & $x$ & - & $x$ & Coma et al. (1995a) \\
\hline & P. clavata & $x$ & $x$ & $x$ & $x$ & Coma et al. (1994) \\
\hline & & Season & Colony size & Intra-colonial & Longevity & \\
\hline \multirow[t]{3}{*}{ Reproduction } & C. everta & $x$ & - & - & $x$ & Coma et al (1996) \\
\hline & P. clavata & $x$ & $x$ & $x$ & - & Coma et al. (1995b) \\
\hline & & Season & Colony size & Intra-colonial & & \\
\hline \multirow[t]{2}{*}{ Growth } & C. everta & $x$ & - & - & & Llobet et al. (1991a) \\
\hline & P. clavata & $x$ & $\times$ & $x$ & & Coma (1994) \\
\hline
\end{tabular}


muricea clavata: season, diel and intra-colonial (position within the colony), and 2 sources of variation in Campanularia everta: season and diel (Table 1). Prey capture rates, expressed as the number of prey items captured per polyp and hour, were calculated using the equation (Coma et al. 1994):

$$
C=N\left[\sum_{t=0}^{D} 1-(t / D)\right]^{-1}
$$

where $C=$ no. of prey captured polyp $\mathrm{p}^{-1} \mathrm{~h}^{-1} ; N=$ prey items per polyp; $t=$ time (in h); and $D=\operatorname{digestion~time~}$ (in h). The different sources of variation together with the maximum observed digestion times of $2 \mathrm{~h}$ for $C$. everta and $4 \mathrm{~h}$ for $P$. clavata were used to calculate the daily energy intake (Table 1). Prey biomass was estimated from their biovolume (Sebens \& Koehl 1984) using conversion factors to wet weight of $(1.025$; Hall et al. 1970), dry weight (13\% of wet weight; Beers 1966), carbon content $(45 \%$ of dry weight; Biswas \& Biswas 1979) and caloric contents (Cummins \& Wuycheck 1971).

Reproductive effort. Gonadal volume per polyp over an annual cycle was calculated by examining 3 sources of variation on Paramuricea clavata: season, colony size and intra-colonial, and 2 sources of variation in Campanularia everta: season and gonangial longevity (Table 1). Dry weight (DW) of gonads and gonangia was established after heating 4 replicates of 200 gonads ( $P$. clavata) and 200 gonangia $(C$. everta) at $70^{\circ} \mathrm{C}$ for $24 \mathrm{~h}$. The carbon content of these replicates was determined in a C:N:H analyzer.

Growth. Growth in Paramuricea clavata was calculated from changes in colony total length over time based on photographic monitoring. Variation was calculated on the basis of season, colony size and position within the colony (intra-colonial, Table 1). Conversion equations for the parameters height, total length, dry weight, and carbon content were calculated based on the results of a biometric study of colonies (Coma 1994). Size classes $(10 \mathrm{~cm}$ size classes) were distinguished base on reproductive status (Coma et al. 1995b).

Colonies of Paramuricea clavata are composed of tissue, a skeletal axis, and spicules, the proportions of which vary according to colony size. The dry weight of the organic matter in the tissue contains $40 \%$ organic carbon; the dry weight of the skeletal axis contains $44 \%$ organic carbon; and the spicules contain $12 \%$ inorganic carbon (Coma 1994). Organic carbon production by the colony was used in the energy budget equation.

In Campanularia everta, changes in individual (hydropolyps and gonangia) densities were examined for a total surface area of $240 \mathrm{~cm}^{2}$ bi-weekly over an annual sampling cycle (621 colonies; Llobet et al. 1991a) Secondary production was calculated according to a modified version of the method of Allen (Holme \& McIntyre 1984). Based on the size frequency distribu- tion (number of hydropolyps), cohorts were identified using the method of Bhattacharya (Bhattacharya 1967) and the ELEFAN program (Gayanilo et al. 1989). This method produces a best-fit normal distribution for each cohort with a calculated mean and standard deviation. Four replicates of 200 polyps were dried at $70^{\circ} \mathrm{C}$ for $24 \mathrm{~h}$ to convert production values, in terms of number of polyps, to dry weight. The carbon content of these same replicates was assessed in a $\mathrm{C}: \mathrm{N}: \mathrm{H}$ analyzer to convert production to carbon weight.

Respiration. The respiratory rate of Paramuricea clavata was measured according to the method of Winkler (Strickland \& Parsons 1968). The most suitable combination of gorgonian biomass, container volume, and incubation time of $0.75 \mathrm{~g} \mathrm{DW}, 240 \mathrm{ml}$ bottles, and 2 h incubation time determined by Coma (1994), which enables the detection of decreases in oxygen concentration without allowing concentrations ever to fall below $90 \%$ of initial levels, was used. Two experiments were carried out in May, 2 in August, and 1 in September 1992. In each experiment, 9 apical fragments were removed, completely cleaned of any macroepibionts, and attached to a PVC frame in their habitat using natural fibers. Twenty-four hours after collection they were incubated separately in situ together with control bottles that contained no colonies. The respiratory rate at ambient temperature, $15^{\circ} \mathrm{C}$ (May), $22^{\circ} \mathrm{C}$ (August), and $19^{\circ} \mathrm{C}$ (September), was measured. At the end of the incubation periods the colonies were heated for $48 \mathrm{~h}$ at $110^{\circ} \mathrm{C}$ and their dry weight measured. Afterwards they were heated at $550^{\circ} \mathrm{C}$ for $5 \mathrm{~h}$ to determine their AFDW. Expansion state of the polyps was recorded throughout the respiration experiments.

A respiratory rate of $2.24 \mathrm{ml} \mathrm{O}_{2} \mathrm{~g}^{-1} \mathrm{DW} \mathrm{h} \mathrm{h}^{-1}$ at $16^{\circ} \mathrm{C}$, as reported by Paffenhöfer (1968) for small colonies of Clava multicornis ( $2 \mathrm{~mm}$ ), was considered to be the nearest available data, in terms of modular size, to that of $C$. everta $(0.6 \mathrm{~mm})$. A $Q_{10}$ of 2.37 was estimated from the field data on Eudendrium glomeratum (Arillo et al. 1989), because it is the only seasonal respiratory study on hydroids in the Mediterranean. This value is consistent with the $Q_{10}$ values (2.4) estimated for aposymbiotic $H y$ dra viridis (Pardy \& Dieckmann 1975). A general $Q_{0 x}$, the energy equivalent for converting rate of oxyen consumption into rate of heat production (cal g $\mathrm{g}^{-1}$ oxygen consumed), of $3380 \mathrm{cal} \mathrm{g}^{-1}$ was used to convert the rate of oxygen consumption to heat production (Elliott \& Davison 1975).

Excretion. In May 1992, 18 Paramuricea clavata apical fragments were removed, completely cleaned of macroepibionts, and attached to a PVC frame in their habitat using natural fibres. After 24 h they were incubated separately in situ for $2 \mathrm{~h}$. The ammonium excretion rate was measured at approximately $15^{\circ} \mathrm{C}$ accord- 
ing to the phenol hypochlorite method (Solórzano 1969) in dark $80 \mathrm{ml}$ bottles. Simultaneously, control incubations were performed using the same equipment and procedure but no colonies. The water used in the incubations had previously been filtered through Whatman GF/F $(0.7 \mu \mathrm{m})$ glass fibre filters. Excretory rates were expressed per unit dry weight of colony.

An NQ (mol of excreted nitrogen per mol of oxygen consumed) of 0.189 reported for Eudendrium racemosum (Barange et al. 1989) was used for Campanularia everta, because, although this species has maximum population in summer (opposite to $C$. everta), this is the only reference to excretion in hydroids in the literature. An ammonium enthalpy of combustion of $83.2 \mathrm{kcal} \mathrm{mol}^{-1}$ (Elliot \& Davison 1975) was used.

Energy budget. The equations describing the energy budget were:

$$
\begin{gathered}
I=G+R+E x+R e p+E g \text { and } \\
A=I-E g(C r i s p 1984)
\end{gathered}
$$

where $I$ = ingesta; $A=$ assimilation; $G=$ growth; $R=$ respiration; Ex = excretion; Rep = reproductive effort; and $\mathrm{Eg}=$ egesta. All fractions in the metabolic budgets were expressed in terms of carbon per polyp and as a proportion of organic carbon weight of tissue (devoid of spicules and skeletal axis in Paramuricea clavata). It was not possible to evaluate the value of either the egesta or assimilation in P. clavata. To bridge this gap. an assimilation efficiency rate $(75 \%)$ was adopted based on the values published for other cnidaria in the literature, which ordinarily ranged between 70 and $80 \%$ (Ivleva 1964, Zamer 1986). Since no studies have been published on species similar to Campanularia everta, an assimilation efficiency rate of $70 \%$, an intermediate value in the range $(60$ to $90 \%)$ reported for other hydroids (Paffenhöfer 1968, Schroeder 1969, Simkina 1980), was used for that species.
Growth efficiency was taken to be the fraction of total ingesta $\left(K_{1}\right)$ or assimilated energy $\left(K_{2}\right)$ available for growth and reproductive effort (Winberg 1971, Crisp 1984). The energy surplus (Sebens 1979, 1982), energy available for growth and reproduction, was calculated by subtracting the basal metabolism ( $R+$ Ex) from the total assimilated energy. Caloric content was estimated on conversion tables from Cummins \& Wuycheck (1971). The energy values reported for tissue, skeleton, and gonad are based on the energy in the constituent chemical compounds.

\section{RESULTS}

\section{Campanularia everta}

Ingesta

Ingestion was significantly greater during the late winter and early autumn, reaching a minimum in June and July and again in December (1-way ANOVA; $F_{10,987}=5.73, \mathrm{p}<0.00001$; Table 2). On average, for the entire range of sizes and all seasons of the year, this hydroid ingests the equivalent of 5 to $74 \%$ (mean: $19 \%$ ) of its weight daily. These values are the equivalent of ingesta values of 0.45 to $6.6 \times 10^{-3} \mathrm{cal} \mathrm{pol}$ (polyps) $)^{-1} \mathrm{~d}^{-1}$ (mean: $1.72 \times 10^{-3} \mathrm{cal} \mathrm{pol}^{-1} \mathrm{~d}^{-1}$ ) or 500 to $7360 \mathrm{cal} \mathrm{g}^{-1} \mathrm{C} \mathrm{d}^{-1}$ (mean: $1915 \mathrm{cal} \mathrm{g}^{-1} \mathrm{C} \mathrm{d}^{-1}$ ).

\section{Somatic growth}

The investment in somatic biomass is concentrated in autumn, winter and early spring (April), falling to minimum levels in the summer and in the month of October (Table 3), when all reproductive effort is

Table 2. Campanularia everta. Monthly prey capture values expressed as number of prey items (OMP: organic matter particles;

\begin{tabular}{|c|c|c|c|c|c|c|c|}
\hline \multirow{2}{*}{ Month } & \multirow{2}{*}{$N$} & \multicolumn{3}{|c|}{ Prey (no. $\mathrm{pol}^{-1} \mathrm{~d}^{-1}$ ) } & \multicolumn{3}{|c|}{ Biomass $\left(\mu g C\right.$ pol $\left.^{-1} \mathrm{~d}^{-1}\right) \times 100$} \\
\hline & & OMP & Zoopl. & Total & OMP & Zoopl. & Total \\
\hline Jan & 50 & $16.4 \pm 2.7$ & $1.6 \pm 0.7$ & $18.0 \pm 2.6$ & $8.2 \pm 1.4$ & $8.1 \pm 3.4$ & $16.3 \pm 2.4$ \\
\hline Feb & 50 & $23.4 \pm 2.3$ & $1.2 \pm 0.4$ & $24.6 \pm 2.3$ & $11.7 \pm 1.1$ & $6.2 \pm 2.0$ & $17.8 \pm 1.7$ \\
\hline Mar & 50 & $23.5 \pm 3.5$ & $0.5 \pm 0.3$ & $24.0 \pm 3.4$ & $11.8 \pm 1.7$ & $2.4 \pm 1.7$ & $14.2 \pm 2.0$ \\
\hline Apr & 50 & $15.9 \pm 1.9$ & $0.9 \pm 0.3$ & $16.8 \pm 1.9$ & $8.0 \pm 1.0$ & $4.4 \pm 1.6$ & $12.4 \pm 1.4$ \\
\hline May & 50 & $20.7 \pm 1.9$ & $0.3 \pm 0.3$ & $21.0 \pm 1.9$ & $10.4 \pm 1.0$ & $1.3 \pm 1.4$ & $11.6 \pm 1.1$ \\
\hline Jun & 50 & $10.2 \pm 1.8$ & $0.0 \pm 0.0$ & $10.2 \pm 1.8$ & $5.1 \pm 0.9$ & $0.0 \pm 0.0$ & $5.1 \pm 0.9$ \\
\hline Jul & 50 & $9.0 \pm 1.0$ & $0.0 \pm 0.0$ & $9.0 \pm 1.1$ & $4.5 \pm 0.5$ & $0.0 \pm 0.0$ & $4.5 \pm 0.5$ \\
\hline Aug & 50 & $13.2 \pm 2.2$ & $0.0 \pm 0.0$ & $13.2 \pm 2.2$ & $6.6 \pm 1.1$ & $0.0 \pm 0.0$ & $6.6 \pm 1.1$ \\
\hline Sep & 50 & $19.0 \pm 2.2$ & $0.8 \pm 0.3$ & $19.8 \pm 2.1$ & $9.5 \pm 1.1$ & $3.8 \pm 1.7$ & $13.3 \pm 1.4$ \\
\hline $\mathrm{Oct}$ & 50 & $20.1 \pm 2.1$ & $3.3 \pm 0.9$ & $23.4 \pm 2.1$ & $10.1 \pm 1.1$ & $16.4 \pm 4.4$ & $26.4 \pm 2.4$ \\
\hline Nov & 50 & $17.3 \pm 2.1$ & $11.5 \pm 0.9$ & $28.8 \pm 2.1$ & $8.6 \pm 1.1$ & $57.6 \pm 4.3$ & $66.2 \pm 4.9$ \\
\hline Dec & 50 & $13.9 \pm 1.0$ & $1.1 \pm 0.8$ & $15.0 \pm 1.1$ & $7.0 \pm 0.5$ & $5.4 \pm 3.8$ & $12.4 \pm 0.9$ \\
\hline
\end{tabular}
Zoopl.: zooplankton\} and carbon (C) units per polyp (pol) per day. Data expressed as mean value \pm standard error 
Table 3. Campanularia everta. (A) Biomass: annual variation in polyp (pol) density (polyps per $240 \mathrm{~cm}^{2}$ ). Monthly somatic production rates expressed as increase in number of polyps per month per $240 \mathrm{~cm}^{2}$ ( $\triangle$ No. pol) and as increase in carbon (C) units per polyp per month. (B) Reproduction: monthly reproductive production values expressed as number of gonangia and carbon units per polyp per month during the spawning period: October-December. Data expressed as mean value \pm standard error

\begin{tabular}{|c|c|c|c|c|}
\hline \multirow[t]{3}{*}{$\begin{array}{l}\text { (A) Growth } \\
\text { Month }\end{array}$} & \multirow{3}{*}{$\begin{array}{c}\text { Biomass } \\
\left(\text { No. pol } / 240 \mathrm{~cm}^{2}\right)\end{array}$} & \multicolumn{3}{|c|}{ Somatic production } \\
\hline & & \multirow{2}{*}{$\begin{array}{c}\Delta \text { No. pol } \\
\left(\text { No. pol mo-1/240 } \mathrm{cm}^{2}\right)\end{array}$} & \multicolumn{2}{|c|}{ Carbon } \\
\hline & & & $\left(\mu \mathrm{gC} \mathrm{pol} \mathrm{l}^{-1} \mathrm{mo}^{-1}\right)$ & $\left(\mu \mathrm{gC} \mathrm{pol} \mathrm{l}^{-1} \mathrm{~d}^{-1}\right) \times 100$ \\
\hline Jan & $1921 \pm 121$ & $4057 \pm 334$ & $1.9 \pm 0.2$ & $6.3 \pm 0.5$ \\
\hline Feb & $1527 \pm 133$ & $1884 \pm 143$ & $1.1 \pm 0.1$ & $3.7 \pm 0.3$ \\
\hline Mar & $2536 \pm 189$ & $1983 \pm 131$ & $0.7 \pm 0.0$ & $2.3 \pm 0.2$ \\
\hline Apr & $2745 \pm 253$ & $3562 \pm 406$ & $1.2 \pm 0.1$ & $3.8 \pm 0.4$ \\
\hline May & $926 \pm 107$ & $787 \pm 125$ & $0.8 \pm 0.1$ & $2.5 \pm 0.4$ \\
\hline Jun & $173 \pm 30$ & $70 \pm 10$ & $0.4 \pm 0.1$ & $1.2 \pm 0.2$ \\
\hline Jul & $78 \pm 20$ & $76 \pm 11$ & $0.9 \pm 0.1$ & $2.9 \pm 0.4$ \\
\hline Aug & $620 \pm 115$ & $495 \pm 134$ & $0.7 \pm 0.2$ & $2.4 \pm 0.6$ \\
\hline Sep & $473 \pm 43$ & $752 \pm 21$ & $1.4 \pm 0.0$ & $4.7 \pm 0.1$ \\
\hline Oct & $789 \pm 82$ & $379 \pm 42$ & $0.4 \pm 0.0$ & $1.4 \pm 0.2$ \\
\hline Nov & $956 \pm 62$ & $1990 \pm 100$ & $1.9 \pm 0.1$ & $6.2 \pm 0.3$ \\
\hline Dec & $1449 \pm 133$ & $689 \pm 68$ & $0.4 \pm 0.0$ & $1.4 \pm 0.1$ \\
\hline \multicolumn{5}{|c|}{ (B) Reproduction } \\
\hline \multirow[t]{3}{*}{ Month } & \multicolumn{4}{|c|}{ Gonad production } \\
\hline & \multicolumn{2}{|c|}{ Gonangia } & \multicolumn{2}{|c|}{ Carbon } \\
\hline & $\mathrm{N} \mathrm{cm}^{-2}$ & $\mu \mathrm{g} \mathrm{C} \mathrm{cm}^{-2}$ & $\mu g \mathrm{C} \mathrm{pol} \mathrm{l}^{-1} \mathrm{mo}^{-1}$ & $\left(\mu \mathrm{gC} \mathrm{pol}{ }^{-1} \mathrm{~d}^{-1}\right) \times 100$ \\
\hline Oct & $203 \pm 0.69$ & $4.24 \pm 1.44$ & $2.67 \pm 0.91$ & $8.76 \pm 2.98$ \\
\hline Nov & $1.61 \pm 0.55$ & $3.36 \pm 1.14$ & $1.05 \pm 0.36$ & $3.45 \pm 1.17$ \\
\hline Dec & $0.07 \pm 0.02$ & $0.14 \pm 0.05$ & $0.05 \pm 0.02$ & $0.16 \pm 0.05$ \\
\hline
\end{tabular}

made. On average, growth represents a daily accumulation of between 1 and $7 \%$ of body weight. This is the equivalent of an investment of between 0.12 and $0.63 \times$ $10^{-3} \mathrm{cal} \mathrm{pol}^{-1} \mathrm{~d}^{-1}$ (133 to $695 \mathrm{cal} \mathrm{g}^{-1} \mathrm{C} \mathrm{d}^{-1}$ ).

\section{Reproductive effort}

Campanularia everta has a clear seasonal pattern of sexual reproduction. Spawning takes place essentially during the month of October, falls off in November, and is merely residual in December (Table 3). In October, $C$. everta invests up to the equivalent of 4 to $10 \%$ of its weight in reproductive effort daily. The investment in gonothecae per polyp during the period of sexual reproduction is on the order of 0.35 to $0.88 \times 10^{-3}$ cal pol $\mathrm{d}^{-1} \mathrm{~d}^{-1}$, or around 380 to $1000 \mathrm{cal} \mathrm{g}^{-1} \mathrm{C} \mathrm{d}^{-1}$

\section{Energy budget}

The respiratory rate selected is the daily equivalent of $7 \%$ of body weight. Accordingly, Campanularia everta consumes in the order of $0.67 \times 10^{-3} \mathrm{cal} \mathrm{pol}^{-1} \mathrm{~d}^{-1}$, or some $734 \mathrm{cal} \mathrm{g}^{-1} \mathrm{C} \mathrm{d}^{-1}$, in respiration. Application of an NQ value of 0.189 to the respiratory rate yields an energy consumption rate of $0.10 \times 10^{-3} \mathrm{cal} \mathrm{pol}^{-1} \mathrm{~d}^{-1}$ for excretion or some $107 \mathrm{cal} \mathrm{g}^{-1} \mathrm{C} \mathrm{d}^{-1}$. The results show that the energy ingested meets energy requirements over most of the year (Fig. 1). The energy surplus was $36 \%$ of assimilated energy; growth efficiency was $25 \%$ $\left(K_{1}\right)$, and net growth efficiency was $45 \%\left(K_{2}\right)$. Estimated respiration and excretion may account for between 38 and $77 \%$ (average: around $60 \%$ ) of total demand. Reproductive effort in October (46\%) may exceed investments in all other categories, but during the rest of autumn, winter, and beginning of spring nearly half of the available energy is invested in growth (Fig. 1). At the beginning of summer, the most critical period in energy terms, the relative rate of investment in growth drops to a fifth of winter levels.

\section{Paramuricea clavata}

\section{Ingesta}

Ingestion significantly varied among months, with the greatest captures in spring and NovemberDecember $\mid F_{11,1324}=6.85, p<0.0001$; ingestion was tested across months, and among colonies with a 2way nested ANOVA (colony nested in month)]. Table 4 
Table 4. Paramuricea clavata. Daily prey capture rates (for each month) according to colony size expressed in carbon units per polyp. Polyps: average number of polyps per colony of each size class. Extrapolated values determined on the basis of the number of polyps per colony and proportion of polyps on the different branch orders. Data expressed as mean value \pm standard error

\begin{tabular}{|c|c|c|c|c|c|}
\hline & $>40$ & $30-40$ & $\begin{array}{c}\text { Colony size }(\mathrm{cm}) \\
20-30\end{array}$ & $10-20$ & $0-10$ \\
\hline Polyps (no.) & $26175 \pm .5782$ & $15312 \pm 2007$ & $8710 \pm 1670$ & $3657 \pm 680$ & $630 \pm 139$ \\
\hline \multicolumn{6}{|c|}{ Prey capture rate $\left(\mu \mathrm{g} \mathrm{C} \mathrm{pol} \mathrm{l}^{-1} \mathrm{~d}^{-1}\right) \times 100$} \\
\hline Jan & $26.7 \pm 6.6$ & $27.5 \pm 6.7$ & $27.2^{\bullet}$ & $28.6^{\circ}$ & $29.4^{\circ}$ \\
\hline Feb & $34.8 \pm 5.9$ & $35.9 \pm 6.0$ & $35.5^{\circ}$ & $37.3^{\circ}$ & $38.4^{\circ}$ \\
\hline Mar & $17.9 \pm 2.2$ & $18.4 \pm 2.2$ & $18.2^{\circ}$ & $19.2^{\bullet}$ & $19.7^{\circ}$ \\
\hline Apr & $40.8 \pm 6.5$ & $42.1 \pm 6.7$ & $41.6^{\circ}$ & $43.8^{\circ}$ & $45.0^{\circ}$ \\
\hline May & $58.2 \pm 9.1$ & $60.0 \pm 9.4$ & $59.3^{\circ}$ & $62.4^{\circ}$ & $64.1^{\circ}$ \\
\hline Jun & $35.1 \pm 6.7$ & $36.1 \pm 6.9$ & $35.7^{\bullet}$ & $37.6^{\circ}$ & $38.6^{\circ}$ \\
\hline Jul & $23.5 \pm 7.3$ & $24.2 \pm 7.6$ & $23.9^{\circ}$ & $252^{\circ}$ & $25.9^{\circ}$ \\
\hline Aug & $28.2 \pm 16.9$ & $29.1 \pm 17.4$ & $28.8^{\circ}$ & $30.3^{\circ}$ & $31.1^{\circ}$ \\
\hline Sep & $23.9 \pm 5.8$ & $24.6 \pm 6.0$ & $24.3^{\circ}$ & $25.6^{\circ}$ & $26.3^{\circ}$ \\
\hline Oct & $26.8 \pm 4.8$ & $27.6 \pm 4.9$ & $27.3^{\circ}$ & $28.7^{\circ}$ & $29.5^{\circ}$ \\
\hline Nov & $58.5 \pm 15.9$ & $60.3 \pm 16.4$ & $59.6^{\circ}$ & $62.7^{\circ}$ & $64.5^{\circ}$ \\
\hline Dec & $46.3 \pm 11.0$ & $47.7 \pm 11.3$ & $47.1^{\circ}$ & $49.6^{\circ}$ & $51.0^{\circ}$ \\
\hline Annual rate $\left(\mu \mathrm{g} \mathrm{C} \mathrm{pol} \mathrm{l}^{-1} \mathrm{yr}^{-1}\right)$ & $128 \pm 30.6$ & $132 \pm 31.6$ & $130^{\circ}$ & $137^{\circ}$ & $141^{\circ}$ \\
\hline
\end{tabular}

summarizes the monthly distribution of ingesta values for Paramuricea clavata obtained by converting the stomach contents for an entire annual cycle to energy units. On average, colonies of this gorgonian ingested daily the equivalent of 0.5 to $1.4 \%$ (mean: $0.8 \%$ ) of the organic carbon weight of their tissues or 0.4 to $1.4 \%$ of colony total dry weight (including the skeletal axis and spicules) for the entire size range over the year. These values are the equivalent of an ingesta of 1.8 to $6.4 \times$ $10^{-3} \mathrm{cal} \mathrm{pol}^{-1} \mathrm{~d}^{-1}$, or 27 to $234 \mathrm{cal} \mathrm{g}^{-1} \mathrm{C} \mathrm{d}^{-1}$.

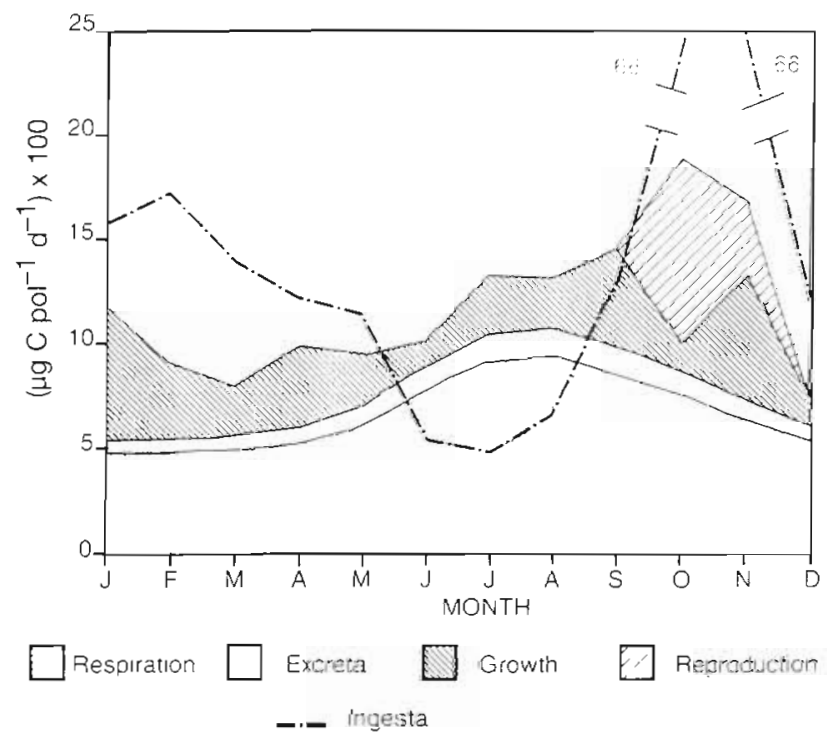

Fig. 1 Campanularia everta. Monthly metabolic flow rates (ingesta, reproduction, growth, respiration, excretion) expressed as carbon units per polyp (pol)

\section{Respiration and excretion}

The main parameters involved in the respiration rate of Paramuricea clavata were temperature, reproductive phase and activity rhythm (Fig. 2). Usually, polyps of the same colony show the same pattern of activity (open or closed). There were significant differences in respiration between the colonies with polyps expanded or contracted (2-way ANOVA; $F_{1,36}=116.56$, $\mathrm{p}<0.0001$ ). However, respiration rate did not significantly vary with temperature (2-way ANOVA; $F_{136}=$ $0.14, p<0.7079$ ), and the interaction of both factors (activity and temperature) was not significant (2-way ANOVA, $F_{1.36}=0.23, p<0.6313$ ). Colonies with polyps contracted decreased their respiratory rate about $50 \%$. The respiration rate in May $\left(15^{\circ} \mathrm{C}\right)$ was as high as in August $\left(22^{\circ} \mathrm{C}\right)$. The respiration rate in September $\left(19^{\circ} \mathrm{C}\right)$ was lower than in May $\left(15^{\circ} \mathrm{C}\right)$. This probably was because apical fragments are involve in reproduction (Coma et al. 1995b), and the energy investment in gonadal development in May is at its highest point whereas there was no energy investment in gonadal development in August and September.

Therefore, because our experiments cannot distinguish between the effects of temperature and the effects of energy investment in growth and reproduction, we calculated a mean respiration rate of colonies for all temperatures. Mean respiration rate of colonies with expanded polyps was $398(\mathrm{SD}=54) \mu \mathrm{g} \mathrm{O}_{2} \mathrm{~g}^{-1}$ AFDW h $\mathrm{h}^{-1}$ and mean respiration rate of colonies with contracted polyps was $210(\mathrm{SD}=40) \mu \mathrm{g} \mathrm{O}_{2} \mathrm{~g}^{-1}$ AFDW h $\mathrm{h}^{-1}$. To estimate the daily investment in respiration over the entire year, we applied a correction factor based on the annual 
Fig. 2. Paramuricea clavata. Monthly mean sea temperature $(\Delta)$ in the study area $\left({ }^{\circ} \mathrm{C}\right)$, respiratory rate $\left(\mathrm{mg} \mathrm{O}_{2} \mathrm{~g}^{-1} \mathrm{AFDW}^{-1}\right.$ $\mathrm{h}^{-1}$; (O) colonies with expanded polyps; ( $\bullet$ colonies with contracted polyps), and activity rhythm ( $\square$, percentage of expanded colonies, redrawn after Coma et al. 1994). Mean monthly reproductive effort $\left[\left(\mu \mathrm{g} \mathrm{C} \mathrm{pol}{ }^{-1} \mathrm{~d}^{-1}\right) \times 100\right]$ for each sex
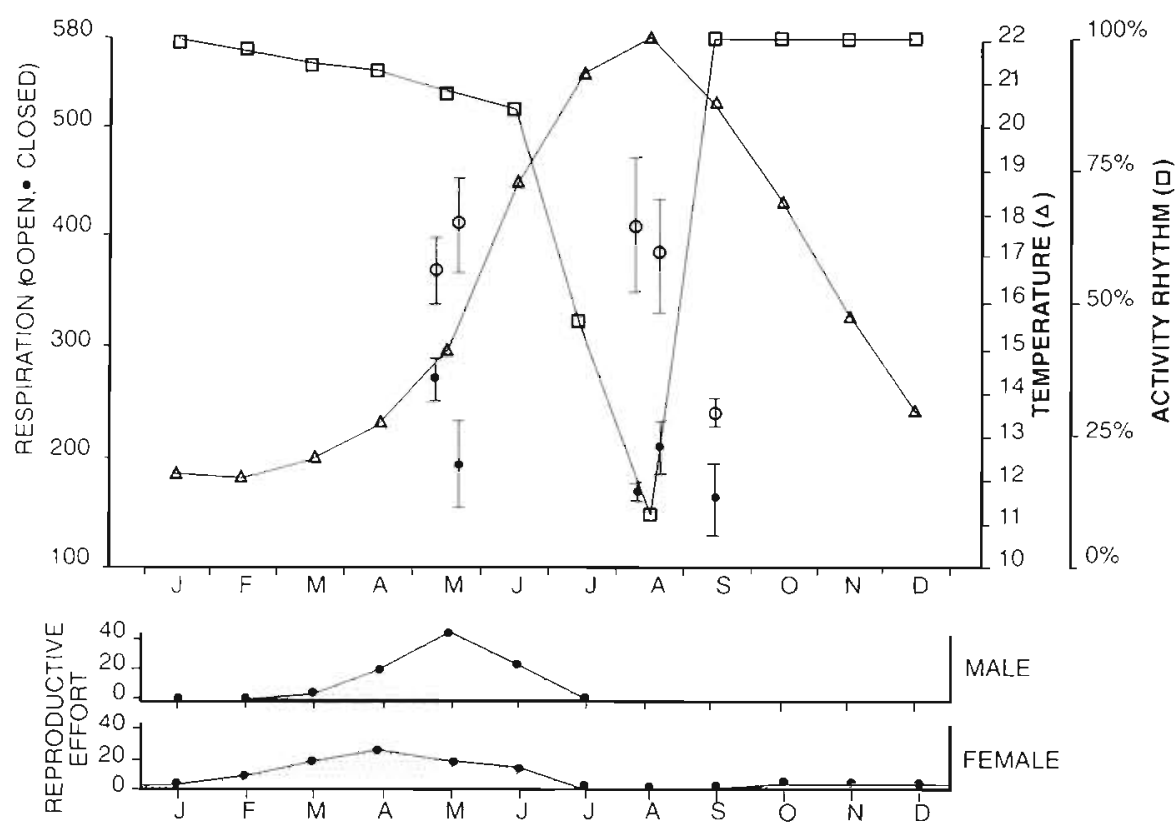

activity rhythm (percentage of expanded colonies) from Coma et al. (1994). Respiratory rates measured in the incubators were highly consistent with the rates reported for gorgonians in other parts of the world (Lewis \& Post 1982, Sebens 1987). These values imply that respiration by polyps is the equivalent of 4.7 to $6.6 \times 10^{-3} \mathrm{cal} \mathrm{pol}^{-1} \mathrm{~d}^{-1}$ or that respiration in Paramuricea clavata consumes some $100 \mathrm{cal} \mathrm{g}^{-1} \mathrm{C} \mathrm{d}^{-1}$. These do not appear to be very high values, in that they represent a daily consumption of the calorie equivalent of only $1 \%(0.9$ to 1.3$)$ of the organic carbon weight of tissue in this gorgonian species, whereas in other coelenterates daily respiratory requirements equivalent to $7-15 \%$ of body weight have been reported (Barange et al. 1989).

The excretory rate was estimated at $1.16(\mathrm{SD}=$ 0.6) $\mu \mathrm{M} \mathrm{NH}_{4} g^{-1}$ AFDW h$h^{-1}$ at $15^{\circ} \mathrm{C}$. A polyp excretes daily $0.0036 \mu \mathrm{mol} \mathrm{NH}_{4}$, the equivalent of $0.3 \times 10^{-3} \mathrm{cal}$ pol $^{-1} \mathrm{~d}^{-1}$; therefore, excretion in Paramuricea clavata consumes $5.8 \mathrm{cal} \mathrm{g} \mathrm{C}^{-1} \mathrm{~d}^{-1}$. This value was held constant when computing annual energy requirements, since reliable correction on the basis of temperature or other seasonally variable factors was not possible within the limits of the available data.

\section{Somatic growth}

Growth was significantly higher in spring [1-way ANOVA; $F_{3.163}=8.25, \mathrm{p}<0.0001$ ). Growth rate per apical branch significantly changed with colony size $\left(F_{4,909}=17.02, \mathrm{p}<0.0001 ;\right.$ growth rate was tested across size and among colonies with a 2 -way nested ANOVA (colony nested in size)]. Growth rate of colonies below $20 \mathrm{~cm}$ was higher than growth of colonies above $20 \mathrm{~cm}$. However, in colonies above $20 \mathrm{~cm}$, growth rate did not vary across colony size (Sheffé post-hoc test). The increased biomass produced by growth was subdivided into tissue and skeletal biomass, since both fractions are organic but have differing proportions of carbon and combustion energy values. The investment in somatic biomass was mainly concentrated in spring and fell to its lowest levels in summer and fall (Table 5). On average growth represented a daily accumulation of 0.02 to $0.10 \%$ of body weight for tissue and 0.08 to $0.19 \%$ for skeleton. Overall, the investment was between 0.08 and $0.15 \times 10^{-3} \mathrm{cal} \mathrm{pol}^{-1} \mathrm{~d}^{-1}$ in tissue growth and between 2 and 4 times higher $\left(0.21\right.$ to $0.37 \times 10^{-3} \mathrm{cal}$ pol $^{-1} \mathrm{~d}^{-1}$ ) in skeletal growth, which means that Paramuricea clavata invests between 1 and $14 \mathrm{cal} \mathrm{g}^{-1} \mathrm{C}$ $\mathrm{d}^{-1}$ in tissue growth and between 5 and $29 \mathrm{cal} \mathrm{g}^{-1} \mathrm{C}$ $\mathrm{d}^{-1}$ in skeletal growth.

\section{Reproductive effort}

Table 6 summarizes the monthly energy investment in reproductive effort calculated for the 2 sexes according to colony size. Reproductive effort increases with colony size and is concentrated in the period from March to June (Table 6, Fig. 2). During this period, Paramuricea clavata invests the daily equivalent of 0.4 to $0.7 \%$ of its tissue weight in reproductive effort, whereas reproductive investment is negligible during the rest of the year. A polyp on a sexually mature female colony $(>20 \mathrm{~cm}$ in height) 
Table 5. Paramuricea clavata. Energy demand for colony somatic production expressed as organic carbon units for tissue and skeleton according to colony size and season. Colony: mean total length and biomass per colony of each size class. Annual production: annual growth rate expressed as increase in total length ( $\Delta$ Length), tissue mass and skeletal mass per colony of each size class. "Extrapolated values determined on the basis of the seasonality observed in the measured size classes. Data ixpressed as mean value \pm standard error

\begin{tabular}{|c|c|c|c|c|c|c|}
\hline $\begin{array}{l}\text { Size } \\
(\mathrm{cm})\end{array}$ & $\begin{array}{l}\text { Colony } \\
\text { Length } \\
(\mathrm{cm})\end{array}$ & \multicolumn{2}{|l|}{$\begin{array}{l}\text { Biomass } \\
\text { (mg C) }\end{array}$} & $\begin{array}{l}\Delta \text { Length } \\
(\mathrm{cm})\end{array}$ & $\begin{array}{l}\text { nual productio } \\
\text { Tissue mass } \\
\text { (mg } C y^{-1} \text { ) }\end{array}$ & $\begin{array}{l}\text { Skeletal mass } \\
\left(\mathrm{mg} \mathrm{C} \mathrm{yr}^{-1}\right)\end{array}$ \\
\hline $0-10$ & $18 \pm 6.4$ & $17.4 \pm 3.9$ & & $7 \pm 1.5$ & $6.2 \pm 1.7$ & $12.3 \pm 3.3$ \\
\hline $11-20$ & $105 \pm 21.1$ & $156.3 \pm 29.2$ & & $15 \pm 3.0$ & $21.2 \pm 4.5$ & $58.0 \pm 12.1$ \\
\hline $21-30$ & $246 \pm 47.2$ & $466.6 \pm 91.7$ & & $37 \pm 8.2$ & $64.3 \pm 15.8$ & $197.4 \pm 48.8$ \\
\hline $31-40$ & $426 \pm 51.5$ & $1021.0 \pm 136.6$ & & $49 \pm 7.6$ & $114.2 \pm 15.5$ & $456.1 \pm 64.8$ \\
\hline$>41$ & $728 \pm 160.3$ & $1743.0 \pm 382.6$ & & $61 \pm 9.5$ & $134.7 \pm 24.1$ & $511.1 \pm 88.6$ \\
\hline \multicolumn{2}{|c|}{$\begin{array}{l}\text { Seasonal growth } \\
\left(\mu \mathrm{g} \mathrm{C} \mathrm{pol}^{-1} \mathrm{~d}^{-1}\right) \times 100\end{array}$} & \multicolumn{5}{|c|}{$\begin{array}{l}\text { Colony size }(\mathrm{cm}) \\
21-30\end{array}$} \\
\hline Winter & $\begin{array}{l}\text { Tissue } \\
\text { Skeletal }\end{array}$ & $\begin{array}{l}3.0 \pm 0.8 \\
6.0 \pm 1.6\end{array}$ & $\begin{array}{l}1.8 \pm 0.4 \\
4.9 \pm 1.0\end{array}$ & $\begin{array}{l}2.3^{\circ} \\
7.0^{\circ}\end{array}$ & $\begin{array}{l}2.3^{\circ} \\
9.1^{\circ}\end{array}$ & $\begin{array}{l}1.6^{\circ} \\
6.0^{\circ}\end{array}$ \\
\hline Spring & $\begin{array}{l}\text { Tissue } \\
\text { Skeletal }\end{array}$ & $\begin{array}{l}4.0 \pm 1.1 \\
7.9 \pm 2.1\end{array}$ & $\begin{array}{l}2.3 \pm 0.5 \\
6.4 \pm 1.3\end{array}$ & $\begin{array}{l}3.0^{\circ} \\
9.2\end{array}$ & $\begin{array}{l}3.0^{\circ} \\
12.1^{\circ}\end{array}$ & $\begin{array}{l}2.1^{\circ} \\
7.9^{\circ}\end{array}$ \\
\hline Summer & $\begin{array}{l}\text { Tissue } \\
\text { Skeletal }\end{array}$ & $\begin{array}{l}2.1 \pm 0.6 \\
4.3 \pm 1.2\end{array}$ & $\begin{array}{l}1.3 \pm 0.3 \\
3.5 \pm 0.7\end{array}$ & $\begin{array}{l}1.6^{\circ} \\
5.0^{\circ}\end{array}$ & $\begin{array}{l}1.6^{\circ} \\
6.5^{\circ}\end{array}$ & $\begin{array}{l}1.1^{\circ} \\
4.3^{\circ}\end{array}$ \\
\hline Fall & $\begin{array}{l}\text { Tissue } \\
\text { Skeletal }\end{array}$ & $\begin{array}{l}1.6 \pm 0.4 \\
3.2 \pm 0.9\end{array}$ & $\begin{array}{l}1.0 \pm 0.2 \\
2.6 \pm 0.5\end{array}$ & $\begin{array}{l}1.2^{\circ} \\
3.7^{\circ}\end{array}$ & $\begin{array}{l}1.2^{\circ} \\
4.9^{\circ}\end{array}$ & $\begin{array}{l}0.8^{\circ} \\
3.2^{\circ}\end{array}$ \\
\hline
\end{tabular}

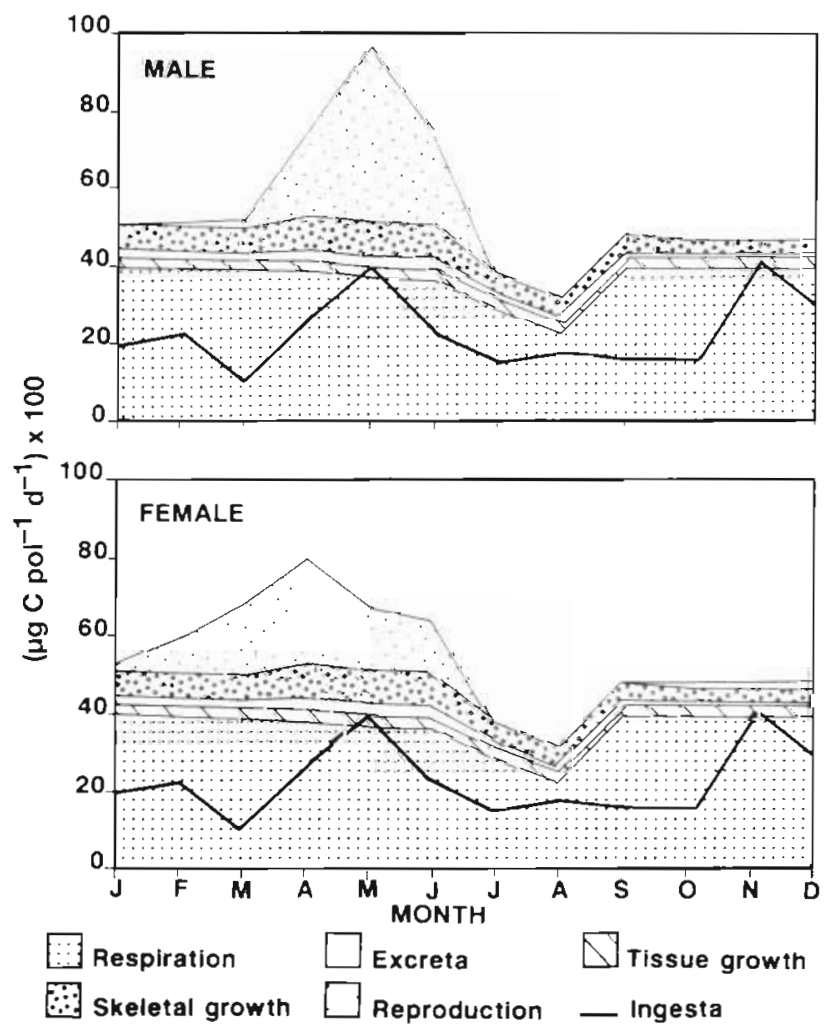

Fig. 3. Paramuricea clavata Mean monthly metabolic demand (ingesta, respiration, excretion, growth, and reproduc-

tion) for a colony of mean size for each sex. pol: polyp invests between 2 and $4.1 \times 10^{-3} \mathrm{cal} \mathrm{pol}^{-1} \mathrm{~d}^{-1}$, the equivalent of some 40 to $78 \mathrm{cal} \mathrm{g}^{-1} \mathrm{C} \mathrm{d}^{-1}$, in spring. Though the daily investment of a primary male polyp may be half again as high as that of a female polyp in May, averaged over the entire year, investment by the 2 sexes is rather similar, and a single value obtained by averaging the estimates for the 2 sexes was therefore used in subsequent calculations.

\section{Energy budget}

The energy budget is presented for mean colony size of each sex in Fig. 3. Although the assimilation efficiency rate selected (75\%) may be somewhat conservative, it is clear that irrespective of the value chosen, the calculations could not be balanced, because the energy value of zooplanktonic prey items accounted for $50 \%$ of demand. The total energy flow through Paramuricea clavata is no more than $150 \mathrm{cal}$ $\mathrm{g}^{-1} \mathrm{C} \mathrm{d}^{-1}$. Total daily energy demand is $1.43 \%$ of tissue (coenenchyme) weight or $3 \%$ of total dry weight, yielding a biomass turnover time of 9 yr (total investment in growth is $10 \%$ of the total energy flow). Total daily energy requirements did not seem to vary significantly $\left(1.30\right.$ to $\left.1.52 \% \mathrm{~d}^{-1}\right)$ with colony size. On the other hand, distribution of the total energy demand among the different components of the budget did 
Table 6. Paramuricea clavata. Daily mean male and female gonad production (for each month) according to colony size, in carbon units per polyp. Extrapolated values determined on the base is of the number of polyps per colony and proportion of polyps on the different branch orders. Data expressed as mean value \pm standard error

\begin{tabular}{|c|c|c|c|c|c|}
\hline & $>40$ & $30-40$ & $\begin{array}{c}\text { olony size ( } \\
20-30\end{array}$ & $10-20$ & $0-10$ \\
\hline \multicolumn{6}{|c|}{ Female gonad production $\left(\mu \mathrm{g} \subset \mathrm{pol}^{-1} \mathrm{~d}^{-1}\right) \times 100$} \\
\hline Jan & $5.3 \pm 0.4$ & $4.2 \pm 0.2$ & $1.7^{\circ}$ & $0.1^{\circ}$ & $0.00^{\circ}$ \\
\hline Feb & $21.3 \pm 1.7$ & $16.9 \pm 0.9$ & $6.9 \cdot$ & $0.6^{\circ}$ & 0.02 \\
\hline Mar & $42.8 \pm 3.5$ & $34.0 \pm 1.9$ & $13.9^{\circ}$ & $1.2^{\cdot}$ & $0.03^{\circ}$ \\
\hline Apr & $63.2 \pm 5.1$ & $50.2 \pm 2.8$ & $20.6^{\circ}$ & $1.7^{\circ}$ & $0.05^{\circ}$ \\
\hline May & $39.2 \pm 3.2$ & $31.2 \pm 1.7$ & $12.8^{\circ}$ & $1.1 \cdot$ & $0.03^{\circ}$ \\
\hline Jun & $31.5 \pm 2.6$ & $25.0 \pm 1.4$ & $10.3^{\circ}$ & 0.9 & $0.02^{\circ}$ \\
\hline Jul & $0.0 \pm 0.0$ & $0.0 \pm 0.0$ & $0.0^{\circ}$ & $0.0^{\circ}$ & $0.00^{\circ}$ \\
\hline Aug & $0.0 \pm 0.0$ & $0.0 \pm 0.0$ & $0.0^{\circ}$ & 0.0 & $0.00^{\circ}$ \\
\hline Sep & $0.0 \pm 0.0$ & $0.0 \pm 0.0$ & $0.0^{\circ}$ & $0.0^{\circ}$ & $0.00^{\circ}$ \\
\hline Oct & $3.5 \pm 0.3$ & $2.8 \pm 0.2$ & 1.1. & 0.1. & $0.00^{\circ}$ \\
\hline Nov & $3.5 \pm 0.3$ & $2.8 \pm 0.2$ & 1.1. & $0.1^{\circ}$ & $0.00^{\circ}$ \\
\hline Dec & $5.3 \pm 0.4$ & $4.2 \pm 0.2$ & $1.7^{\circ}$ & $0.1^{\circ}$ & $0.00^{\circ}$ \\
\hline Annual $\left(\mu \mathrm{g} C \mathrm{pol}^{-1} \mathrm{yr}^{-1}\right)$ & $65.6 \pm 5.3$ & $52.1 \pm 2.9$ & $21.4 \pm 2.0$ & $1.8 \pm 0.7$ & $0.05 \pm 0.01$ \\
\hline \multicolumn{6}{|c|}{ Male gonad production $\left(\mu \mathrm{g} \mathrm{C} \mathrm{pol} \mathrm{l}^{-1} \mathrm{~d}^{-1}\right) \times 100$} \\
\hline Jan & $0.2 \pm 0.0$ & $0.2 \pm 0.0$ & $0.1^{\circ}$ & $0.0^{\circ}$ & $0.0^{\circ}$ \\
\hline Feb & $1.1 \pm 0.0$ & $1.1 \pm 0.0$ & $0.5^{\circ}$ & $0.1^{.}$ & $0.0^{\circ}$ \\
\hline Mar & $4.8 \pm 0.2$ & $4.7 \pm 0.2$ & $2.3^{\circ}$ & $0.4^{\circ}$ & $0.0^{\circ}$ \\
\hline Apr & $41.1 \pm 1.3$ & $40.5 \pm 1.3$ & $19.6^{\circ}$ & $3.6^{\circ}$ & $0.4^{\circ}$ \\
\hline May & $88.9 \pm 2.8$ & $87.8 \pm 2.8$ & $42.4^{\circ}$ & $7.9^{\circ}$ & $0.9^{.}$ \\
\hline Jun & $46.9 \pm 1.5$ & $46.3 \pm 1.5$ & $22.4^{\circ}$ & $4.2^{\circ}$ & $0.5^{\circ}$ \\
\hline Jul & $0.0 \pm 0.0$ & $0.0 \pm 0.0$ & $0.0^{\circ}$ & $0.0^{\circ}$ & $0.0^{\circ}$ \\
\hline Aug & $0.0 \pm 0.0$ & $0.0 \pm 0.0$ & $0.0^{\circ}$ & $0.0^{\circ}$ & $0.0^{\circ}$ \\
\hline Sep & $0.0 \pm 0.0$ & $0.0 \pm 0.0$ & $0.0^{\circ}$ & $0.0^{\circ}$ & $0.0^{\circ}$ \\
\hline Oct & $0.0 \pm 0.0$ & $0.0 \pm 0.0$ & $0.0^{\circ}$ & $0.0^{\circ}$ & $0.0^{\circ}$ \\
\hline Nov & $0.0 \pm 0.0$ & $0.0 \pm 0.0$ & 0.0 & $0.0^{\circ}$ & $0.0^{\circ}$ \\
\hline Dec & $0.2 \pm 0.0$ & $0.2 \pm 0.0$ & 0.1 . & $0.0^{\circ}$ & $0.0^{\circ}$ \\
\hline Annual $\left(\mu \mathrm{gC} \mathrm{pol}-1 \mathrm{yr}^{-1}\right)$ & $55.7 \pm 1.8$ & $55.0 \pm 1.8$ & $26.6 \pm 3.6$ & $5.0 \pm 0.9$ & $0.6 \pm 0.1$ \\
\hline
\end{tabular}

vary with colony size (Fig. 4). Respiration was the largest fraction, with a value from 70 to $82.6 \%$ of total demand; excretion may account for 3.8 to $4.4 \%$ of the total. Investments in growth and reproductive effort accounted for the remaining 12.1 to $24.3 \%$, the proportion varying according to colony size. Small, infertile colonies invest the full $20 \%$ in growth, whereas by the end of the year large colonies will have invested $16 \%$ in sexual reproduction and only the remaining 6.7 to $10 \%$ in growth.

\section{Comparison of budgets}

A comparison of the resource allocation strategies of these 2 species may be undertaken provided that 2 conditions are fulfilled: (1) physiologically active tissue and structural material (virtually non-existent in the hydroid) are considered separately for Paramuricea clavata growth, and (2) the components of the budgets are expressed per modular unit. To remove the variation caused by seasonal factors and colony size, the most rel- evant values for such a comparison are presented in condensed form in Table 7 . Overall metabolic demand per unit of mass is an order of magnitude (10 to 20 times) higher in the hydroid than in the gorgonian (and 50 to 100 times higher if structural material is included in the weight of both species). In both cases respiration is the most important fraction of the energy demand.

Growth is much slower in Paramuricea clavata than in the hydroid (the daily equivalent of $0.15 \%$ of tissue weight). The biomass renewal rate for the gorgonian is on the order of $6.6 \mathrm{yr}$, and the turnover rate is estimated to be $9 \mathrm{yr}$, while in the hydroid the values are 5 and $12 \mathrm{~d}$, respectively. The reason for this is, while in Campanularia everta residual mineral matter corresponding to structurad material accounts for no more than $6 \%$ of the weight of zooids, the 2 skeletal components of the gorgonian (the flexible skeleton of spicules and the organic skeletal axis) account for 54 and $35 \%$, respectively, of colonies' the total biomass (the leftover $11 \%$ was the mean tissue mass).

Assuming that the energy cost of excretion is comparable in both species (6 to $8 \%$ ), the distribution of 

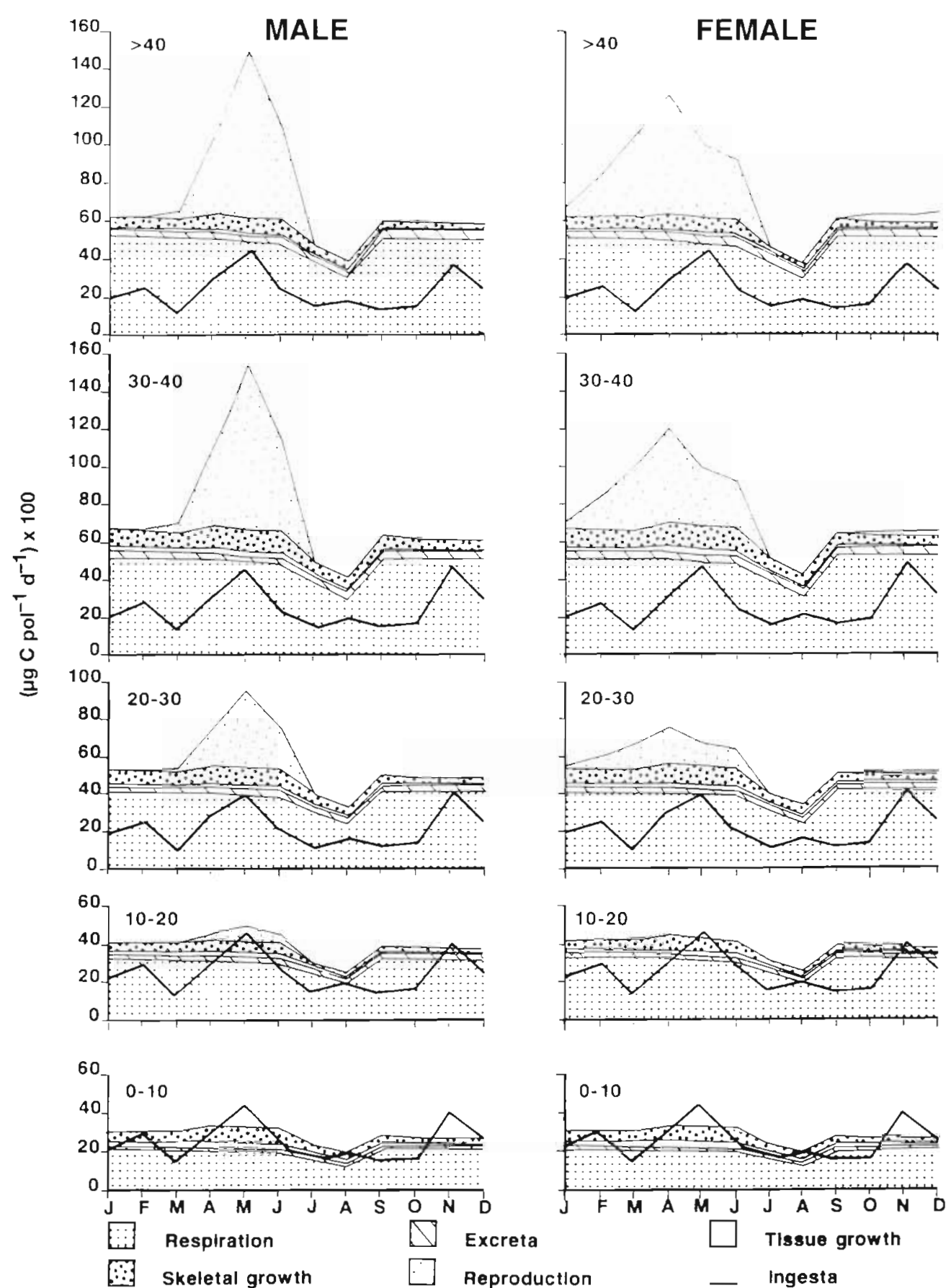

Fig. 4. Paramuricea clavata. Distribution of monthly metabolic demand (ingesta, respiration, excretion, growth, and reproduction) according to colony size class and colony sex. pol: polyp

the energy surplus differed considerably: the energy surplus in the hydroid (about $44 \%$ of the total assimilated energy) is invested mainly (75\%) in somatic growth, the rest $(25 \%)$ in reproductive effort; in the gorgonian, the much smaller energy surplus (nearly $25 \%$ of an amount 10 times smaller) is distributed much more evenly between reproductive effort (50\%) and somatic growth $(50 \%)$. The distribution pattern of the small energy surplus changed with colony age. On average, sexual maturity is delayed until colonies have reached a height of 20 (11 to 30$) \mathrm{cm}$, representing, according to our estimates, an age of 13 (6 to 19) yr. Up to that point, all annual energy surplus is invested in growth. However, from the time of sexual 
Table 7 Campanularia everta and Paramuricea clavata. Mean average value of the components of the energy budgets of both species (ingestion, assimilation, reproduction, growth, respiration, and excretion). Percentage (\%): percentage of each component of the total output. Data expressed as mean value \pm standard error

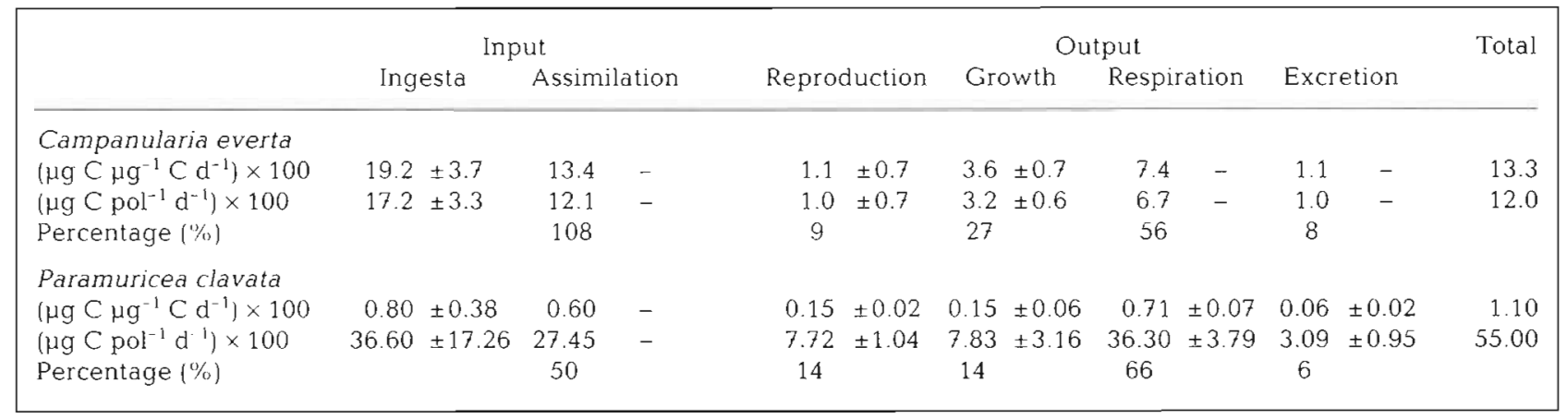

maturity, the annual investment in growth by colonies is divided between somatic growth and sexual reproduction. In a colony $25 \mathrm{~cm}$ tall, roughly $16 \mathrm{yr}$ of age, $56 \%$ of the surplus energy $(10.7 \%$ of the total $)$ is invested in growth and $44 \%$ in reproductive effort, whereas in a colony $50 \mathrm{~cm}$ tall, approximately $30 \mathrm{yr}$ of age, the shares are $38 \%(6.7 \%$ of the total $)$ in growth and $62 \%$ in reproduction.

\section{DISCUSSION}

\section{Energy budgets: are they in balance?}

\section{Paramuricea clavata}

The error terms in growth and reproduction estimations are small enough so that they would not significantly affect the distribution of energy among the different components of the budget. Basal metabolism is responsible for the higher energy demand. The error term in respiration was also small. Although a detailed seasonal respiratory study would provide a better approach to evaluating the respiratory cost of the species, the discrepancy between the energy values for the zooplankton prey ingesta and energy demand is too high to be eliminated by the error terms of the other components of the budget.

Therefore, even though respiration and excretion have not been studied as thoroughly as the other processes, this preliminary budget points to an obvious conclusion: the zooplanktonic prey items present in the stomach contents, basically copepod eggs and nauplii, cannot be the only source of food in the diet of Paramuricea clavata. Prey digestion time is a key factor, since lowering the value by half would suffice to offset the discrepancies and balance the budget. The value for digestion time used ( $4 \mathrm{~h}$ ) may be somewhat conservative, since eggs and nauplii make up the bulk of prey items captured and are digested in a shorter time, with $4 \mathrm{~h}$ being the digestion time for adult copepods. Extrapolating this consideration to the smaller sizes raises the question of whether this gorgonian might not exploit the same amorphous particulate matter that forms the basis of the diet of the hydroid Campanularia everta. Other possible food sources should also be explored.

In order to not overestimate the respiratory costs, the mean respiration value was calculated considering that contracted colonies have a lower basal metabolism (approximately $50 \%$ ). This approach is in accordance with observations in the studies on expansion and contraction in anemones and alcyonaceans (Robbins \& Shick 1980, Sebens 1987), where the respiratory rate of contracted individuals was only 10 to $60 \%$ of the respiratory rate of the same individuals in their expanded state. The experiments performed with Paramuricea clavata during a period of low temperature but with high energy investment in gonadal development (May) and during a period of high temperature and zero reproductive investment result in very similar respiratory rates. Both phenomena, high temperature and high reproductive investment, could produce an increase in $\mathrm{O}_{2}$ consumption. For this reason it was not possible to calculate a $Q_{10}$ for this species, and a mean value of $\mathrm{O}_{2}$ consumption was considered for the entire year. However, this could be an overestimation during autumn and winter because during these periods temperature is low and the energy investment in reproduction and growth is also low.

\section{Campanularia everta}

The values recorded for Campanularia everta agree with the limited amount of available information (see Gili \& Hughes 1995 for review). The average annual ingestion rate $(19.1 \%)$ and growth efficiency $\left(K_{1}: 25 \%\right.$ 
$K_{2}: 47.6 \%$ ) calculated for $C$. everta are similar to those reported by Paffenhöfer (1968) for clones of Clava multicornis in the North Sea, and somewhat lower than the estimates for Eudendrium racemosum ( $K_{1}: 25.9 \%$; $K_{2}: 58.4 \%$ ) reported by Barange et al. (1989). However, it should be recalled that those last workers calculated the energy balance for the period of peak proliferation of that seasonal hydroid.

The error term of each one of the measured parameters of the budget was not large enough to significantly modify the reported trend in the pattern of energy allocation of the species. However, bearing in mind that the components of the budget related to respiration are still provisional, the budget calculated for Campanularia everta yielded a quite acceptable balance between the inputs and expenditures. According to the equation, at an assimilation efficiency rate of $70 \%$ (Paffenhöfer 1968), the material from the stomach contents, primarily amorphous particulate matter digested in $2 \mathrm{~h}$ and consumed continuously throughout the day, would suffice to meet this hydroid's energy needs.

\section{Are somatic and reproductive investments limited by energetic constraints?}

The low density of prey items in summer reduces energy inputs of Campanularia everta to a low level capable of meeting no more than $50 \%$ of metabolic requirements, even at their minimum levels at that time. The fact that minimum metabolic demand coincides in summer with minimum stomach contents and with the period when $C$. everta colonies are in a state of regression (Llobet et al. 1991a) suggests that a trophic-energetics phenomenon may underlie this summer regression. Such a trophic energy-limiting basis for the summer regression in the activity of $C$. everta would also be consistent with the pattern observed in the gorgonian. The energy surplus of Paramuricea clavata is limited during a long season of the year by the precarious balance between food inputs and metabolic demands. As shown by Coma et al. (1994), a significant correlation exists between the annual cycle of planktonic density and the annual cycle of prey content in $P$. clavata stomachs. As planktonic supply decreases sharply in summer, it is not surprising that $P$. clavata has minimum stomach contents and minimum metabolic requirements and spends much more time contracted in summer than during the rest of the year. Thus, somatic and reproductive investments of the gorgonian $P$. clavata may be regulated by trophic constraints.

Regression or inactivity of colonies in summer is not limited to these species, but has been observed in the life cycles of a number of seasonal benthic suspension feeders in the Mediterranean, including hydroids (Boero et al. 1986, Llobet et al. 1991a), tunicates (Turón $\&$ Becerro 1992) and bryozoans (Zabala 1983) However, this pattern cannot be extrapolated to all suspension feeders, because some large hydrozoan species such as Halocordyle disticha and Eudendrium racemosum are at a population maximum during summer (Boero \& Fresi 1986). It appears that the beginning of summer in the Mediterranean, a time of year that is energetically adverse for some suspension feeders, triggers a decline in the abundance of species such as Campanularia everta, combined with lower activity levels (a form of 'aestivation' analogous to the phenomenon of hibernation in many species in colder climates) in perennial species such as the gorgonian Paramuricea clavata. Worsening feeding conditions have been observed to induce cutbacks in colony growth or reproductive effort in several species of benthic modular organisms (Yamaguchi 1975, Jebram 1980). In hydrozoans, lower somatic growth may not be accompanied by loss of stolons, which may continue to grow or may encyst while awaiting sufficient food to support renewed budding of new hydranths (Crowell 1961, Braverman 1971).

The energy budgets of both species include some component values from the literature. From these values, respiration in Campanularia everta evidently is the only component that may have the quantitative importance to produce significant modifications on the budget. A variation in the respiratory estimate in the order of $25 \%$ would produce an increase or decrease of $30 \%$ of the energy surplus. However, the trend in the pattern of energy allocation would not become significantly modified. In autumn and winter, except in December, the energy surplus was always large enough to account for respiration to be up to $25 \%$ higher than the value estimated. In spring, if respiration were $25 \%$ higher, the summer energetic shortfall would occur earlier (about April). During summer time, a higher respiration would make the energetic shortfall even more severe. However, the summer energetic shortfall would persist even if respiration estimates were $25 \%$ lower (Fig. 1)

\section{Resource allocation strategies and life histories}

Despite the differences in colony size, colonization and growth strategy of the 2 species studied, they both exhibited similarities in reproductive tactics. Besides similarities in egg size and egg production (Coma et al. 1995 b, c, 1996), they both concentrate their reproductive effort during a certain time of the year, which seems to be governed by 2 important environmental 
factors: (1) food availability which allows gamete production and development (Kojis \& Quinn 1981, 1982 in corals); and (2) substratum availability for larval settlement (Nishihira 1967, Buss 1979 in hydroids). Both factors maximize the survival of offspring. Both species invest all their sexual reproductive effort in 1 of the 2 most favourable times of year in the Mediterranean from the standpoint of food availability (spring and autumn), when secondary plankton production peaks (Valentin 1972). In both species these 2 periods also coincide with maximum ingestion rates. In autumn Paramuricea clavata invests part of the assimilated energy to initiate of gonad formation, while Campanularia everta invests in the formation of gonangia, producing larvae within a few days. In spring both species appear to accumulate energy in preparation for the summer food shortage (see the preceding section). Both anthozoans (Kellogg \& Patton 1983) and hydrozoans (Bouillon 1995) have been reported to accumulate reserves (lipids), taking the form of stolons in the latter. But, while $P$. clavata spawning occurs in spring, $C$. everta releases its larvae in autumn, when the greatest algal surface area is available for larval settlement (Llobet et al. 1991a). In spring and summer, algal discs are colonized by epiphytic algae and other organisms that block settlement by the hydrozoan's larvae (Boero \& Fresi 1986, Llobet et al. 1991b). Therefore, even though spring would be a favourable period for larval production regarding the high ingestion rate, substratum availability may be a limiting factor that causes the postponement of the release of larvae. In this way the probable accumulation of energy in the stolons enables colonies to produce new hydranths and gonangia rapidly after the food storage has passed.

The picture produced by comparing the energy budgets and ecological strategies of the hydroid Campanularia everta and the gorgonian Paramuricea clavata are quite consistent with the predictive framework for sedentary clonal animals (Hughes \& Cancino 1985). These may be described as 2 opposing life-history strategies: (1) Species of ephemeral clones follow a life strategy based on maximizing clonal expansion by uninterrupted modular iteration as long as conditions are favourable to growth, and holding sexual reproduction in reserve for periods when modular survival or replication is hindered by the environment (Karlson 1988, Hughes 1989). (2) Modules that dwell in persistent habitats may aggregate to form dense colonies, making them more resistent to competition and environmental hazards (Jackson 1977, Buss 1979) and leading to perennation and defense of the space they have taken over (Jackson 1985). This is mainly due to the differing natures of the substrata. Adaptation to the substratum is achieved by means of differing somatic biomass turnover rates, which are much higher in $C$. everta. Yet substratum limitations do not seem to prevent reproductive effort from being very similar in these 2 species. In terms of colony size, since $P$. clavata does not face substratum constraints, it is able to achieve a much larger colony size than $C$. everta.

A species' life-history traits are related to the investment of energy in reproduction as determined by the interaction between the genotype and the environment (Begon \& Mortimer 1985, Begon et al. 1990). Both these species employ the same reproductive strategies irrespective of the substrata they inhabit. This reproductive strategy is characterized by the release of larvae with a short planktonic phase that rarely drift far away from the parent colonies (Coma et al. 1995c, 1996). These species increase their reproductive effort in agreement with colony size, clearly demonstrated in Paramuricea clavata but likewise demonstrable in Campanularia everta. In this latter species, colony size (number of feeding hydranths) in spring will determine the amount of energy stored in the stolons, which in turn will determine both the number of hydranths and gonangia that will be generated rapidly after the critical period of lower food availability in summer.

The interpretation proposed here must be considered as a preliminary approach since, although the obtained data have been precisely measured, an important number of published values have been required for the assessment of the components of the energy budget of both species. This implies that interspecific variation and different degrees of precision can constrain reliability of the final interpretation. We are aware that to evaluate the predictable power of an energy budget approach, as first pointed out in this work, many more species should be examined. However, we believe that the energetic approach can provide an important contribution to the understanding of life-history traits of modular colonial organisms, especially in areas with important seasonal variations of the main environmental factors, such as the Mediterranean

Acknowledgements. We thank R. G. Hughes, H. R. Lasker, K. P. Sebens and I. Valiela for their critical reviews of different versions of the manuscript. We are especially indebted to R. N. Hughes and an anonymous reviewer who greatly improved the definitive version of the manuscript. This work was supported by a work MEC research contract to R.C. and by a DGICYT grant, contract number PB91-0906.

\section{LITERATURE CITED}

Arillo A, Bavestrello G, Boero F (1989) Circannual cycle and oxygen consumption in Eudendrium glomeratum (Cnidaria, Anthomedusae): studies on a shallow water population. PSZN I: Mar Ecol 10:289--301

Barange M, Zabala M, Riera T, Gili JM (1989) A general approach to the in situ energy budget of Eudendrium 
racemosum (Cnidaria, Hydrozod) in the Western Mediterranean. Sci Mar 53:423-427

Beers JR (1966) Studies on the chemical composition of the major zooplankton groups in the Sargasso Sea off Bermuda. Limnol Oceanogr 11:520-528

Begon M, Harper JL, Townsend CR (1990) Ecology, individuals, populations and communities, 2nd edn. Blackwell Scientific Publications, Oxford

Begon M, Mortimer M (1985) Population ecology: a unified study of animals and plants, 2nd edn. Blackwell Scientific Publications, Oxford

Bhattacharya CG (1967) A simple method of resolution of a distribution into Gaussian components. Biometrics 23: $115-135$

Biswas AK, Biswas MR (1979) Handbook of environmental data and ecological parameters, Vol 6 . Environmental sciences and applications. International Society for Ecological Modelling, Pergamon Press, Oxford

Boero F, Balduzzi A, Bavestrello G, Caffa B, Vietti R (1986) Population dynamics of Eudendrium glomeratum (Cnidaria, Anthomedusae) on the Portofino promontory (Ligurian Sea]. Mar Biol 92:81-85

Boero F, Fresi E (1986) Zonation and evolution of a rocky bottom hydroid community. PSZN I: Mar Ecol 7:123-150

Bouillon J (1995) Classe des Hydrozoaires. In: Grassé PP (ed) Traité de zoologie: Cnidaires, Hydrozoaires, Scyphozoaires, Cubozoaires, Clénaires. Masson, Paris, p $29-416$

Braverman MH (1971) Studies on hydroid differentiation. VI Regulation of hydranth formation in Podocoryne carnea. J Exp Zool 3:26-37

Buss LW (1979) Habitat selection, directional growth, and spatial refuges: why colonial animals have more hicting places. In: Larwood G, Rosen BR (eds) Biology and systematics of colonial organisms. Academic Press, London, p $459-497$

Caswell $H$ (1982) Life history theory and the equilibrium status of populations. Am Nat 120:317-339

Caswell H (1989) Life-history strategies. In: Cherrett JM (ed) Ecological concepts. Blackwell Scientific Publications, Oxford, p 285-307

Coma R (1994) Energy budget assesssment of two benthic marine cnidarians. PhD thesis, Univ Barcelona (in Spanish and English)

Coma R, Gili JM, Zabala M (1995a) Trophic ecology of a benthic marine hydroid, Campanulana everta. Mar Ecol Prog Ser 119:211-220

Coma R, Gili JM, Zabala M, Riera T (1994) Feeding and prey capture cycles in the aposymbiotic gorgonian Paramuricea clavata. Mar Ecol Prog Ser 115:257-270

Coma R, Llobet I, Gili JM, Zabala M (1996) Quantification of sexual reproduction in a marine benthic hydroid. Mar Biol 125:365-373

Coma R, Ribes M, Zabala M, Gili JM (1995c) Reproduction and cycle of gonadal development in the Mediterranean gorgonian Paramuricea clavata. Mar Ecol Prog Ser 117 : $173-183$

Coma R, Zabala M. Gili JM (1995b) Sexual reproductive effort in the Mediterranean gorgonian Paramuricea clavata. Mar Ecol Prog Ser 117:185-192

Crisp DJ (1984) Energy flow measurements. In: Holme NA McIntyre AD (eds) Methods for the study of marine benthos. IBP Handbook 16, Blackwell Scientific Publications Oxford, p 284-372

Crowell S (1961) Developmental problems in Campanularia In: Berrill NJ (ed) Growth, development and pattern. WH Freeman and Co, San Francisco, p 297-316

Cummins KW, Wuycheck JC (1971) Caloric equivalents for investigations in ecological energetics. Mitt Int Ver Limnol 18:1-158

Elliott JM, Davison W (1975) Energy equivalents of oxygen consumption in animal energetics. Oecologia 19:195-201

Fisher RA (1958) The genetical theory of natural selection, rev edn. Dover Publications, New York

Gayanilo FC, Soriano M, Pauly D (1989) A draft guide to the complete ELEFAN. ICLARM Software 2. International Center for Living Aquatic Resources Management, Manila

Gili JM, Hughes RG (1995) The ecology of marine benthic hydroids. Oceanogr Mar Biol Annu Rev 33:351-422

Hall DJ, Cooper WE, Werner EE (1970) An experimental approach to the production dynamics and structure of freshwater animal communities. Limnol Oceanogr 15: 839-928

Holme NA, McIntyre AD (1984) Methods for the study of marine benthos. IBP Handbook 16, Blackwell Scientific Publications, Oxford

Hughes RN (1989) A functional biology of clonal animals. Chapman and Hall, London

Hughes RN, Cancino JM (1985) An ecological overview of cloning in Metazoa. In: Jackson JBC, Buss LW, Cook RE (eds) Population biology and evolution of clonal organisms. Yale University Press, New Haven, p 153-186

Hughes TP, Jackson JBC (1985) Population dynamics and life histories of foliaceous corals. Ecol Monogr 55:141-166

Ivleva IV (1964) Elements of energetic balance in sea anemones. Tr Sevastop Biol Stady 25:410-428

Jackson JBC (1977) Competition on marine hard substrata: the adaptive significance of solitary and colonial strategies. Am Nat 111:743-767

Jackson JBC (1985) Distribution and ecology of clonal and aclonal benthic invertebrates. In: Jackson JBC, Buss LW and Cook RE (eds) Population biology and evolution of clonal organisms. Yale University Press, New Haven, p 295-355

Jackson JBC, Buss LW, Cook RE (1985) Population biology and evolution of clonal organisms. Yale University Press, New Haven

Jebram D (1980) Influences of the food on the colony forms of Electra pilosa (Bryozoan, Cheilostomata). Zool Jahrb Abt Syst Oekol Geogr Tiere 108:1-14

Karlson RH (1988) Size-dependent growth in two zoanthid species: a contrast in clonal strategies. Ecology 69: 1219-1232

Kellog RB, Patton JS (1983) Lipid droplets, medium of energy exchange in the symbiotic anemone Condylactis gigantea. Mar Biol 75:137-150

Kojis BL, Quinn NJ (1981) Aspects of the sexual reproduction and larval development in the shallow water hermatipic coral, Goniastrea australensis. Bull Mar Sci 31:558-573

Kojis BL, Quinn NJ (1982) Reproductive ecology of two faviid. corals (Coelenterata: Scleractinia). Mar Ecol Prog Ser 8: $251-255$

Lewis JB, Prost EE (1982) Respiration and energetics in West Indian Gorgonacea. Comp Biochem Physiol 71 A:457-459

Llobet I, Coma R, Zabala M, Gili JM, Hughes RG (1991 a) The population dynamics of Orthopyxis crenata (Hartlaub. 1901) (Hydrozoa, Cnidaria) an epiphyte of Halimeda tuna in the Northwestern Mediterranean. J Exp Mar Biol Ecol 150:283-292

Llobet I, Gili JM, Hughes RG (1991b) Horizontal, vertical and seasonal distribution of epiphytic hydrozoa on the alga Halimeda tuna in the Northwestern Mediterranean Sea. Mar Biol 110:151-159

Nishihira M (1967) Dispersal of the larvae of the hydroid, Ser- 
tularella miurensis, in nature. Bull Mar Biol Stn Asamushi 13:49-56

Paffenhöfer GA (1968) Nährungsaufnahme, Stoffumsatz und Energiehaushalt des marinen Hydroidpolypen Clava multicornis. Helgol Meeresunters 8:1-44

Pardy RL, Dieckmann CL (1975) Oxygen consumption by the green hydra, Hydra viridissima. J Exp Zool 194:373-378

Robbins RE, Shick JM (1980) Expansion-contraction behavior in the sea anemone Metridium senile: environmental cues and energetic consequences. In: Smith DC, Tiffon Y (eds) Nutrition in the lower metazod. Pergamon Press, New York, p 101-116

Schroeder L (1969) Population growth efficiencies of laboratory Hydra pseudoligactis (Hyman) population. Ecology 50:81-86

Sebens KP (1979) The energetics of asexual reproduction and colony formation in benthic marine invertebrates. Am Zool 19:683-697

Sebens KP (1982) The limits to indeterminate growth: an optimal size model applied to passive suspension feeders. Ecology 82:209-222

Sebens KP (1987) Coelenterata. In: Pandian TJ, Vernberg FJ (eds) Animal energetics, Vol 1. Academic Press, San Diego, p 55-120

Sebens KP, Koehl MAR (1984) Predation on zooplankton by the benthic anthozoans Alcyonium siderium (Alcyonacea) and Metridium senile (Actiniaria) in the New England subtidal Mar Biol 81:255-271

Simkina RG (1980) A quantitative feeding study of the colonies of Perigonimus megas (Hydroida, Bouigainvillidae). Zool Zh 59:500-506

Solórzano L (1969) Determination of ammonia in natural

Editorial responsibility: Otto Kinne (Editor),

Oldendort/Luhe, Germany waters by the phenolhypochlorite method. Limnol Oceanogr 14:799-801

Stearns SC (1977) The evolution of life history traits: a critique of the theory and a review of the data. Annu Rev Ecol Syst 8:145-171

Stearns SC (1992) The evolution of life histories. Oxford University Press, Oxford

Strickland JDH, Parsons TR (1968) A manual of sea-water analysis. Bull Fish Res Bd Can 167:1-311

Turon X. Becerro MA (1992) Growth and survival of several ascidian species from the northwestern Mediterranean. Mar Ecol Prog Ser 82:235-247

Valentin $J$ (1972) La ponte et les oeufs chez les copépodes du golfe de Marseille: cycle annuel et étude expérimentale. Tethys 4:349-390

Winberg GG (1971) Methods for the estimation of production of aquatic animals. Academic Press, New York

Yamaguchi $M$ (1975) Growth and reproductive cycles of the marine fouling ascidians Cliona intestinalis, Stylea pilata. Botrylloides violaceus and Leptoclinum mitsukurii at Aburatsubo-Morioso Inlet (central Japan). Mar Biol 29: 253-259

Zabala M, Ballesteros E (1989) Surface-dependent strategies and energy flux in benthic marine communities or why corals do not exist in the Mediterranean. Sci Mar 53 3-17

Zabala M (1983) Estudi sistemàtic i faunistic dels briozous (Ectoprocta) dels Països catalans. PhD thesis, Univ Barcelona

Zamer WE (1986) Physiological energetics of the intertidal sea anemone Anthopleura elegantissima, I. Prey capture, absorption efficiency and growth. Mar Biol 92:299-314

Submitted: August 18, 1997; Accepted: November 15, 1997 Proofs received from author(s): January 29, 1998 